\title{
Social Knowledge Environments
}

\author{
Social software has changed research and practice in the knowledge management field. \\ Several current trends and research issues offer a new understanding of how social software \\ has changed this research field, as well as how scholars in business and information systems \\ engineering (BISE) should take up this emerging research field. The article offers a review of \\ such trends and a framework for addressing the remaining issues.
}

DOI 10.1007/s12599-014-0318-4

\section{The Authors \\ Prof. Dr. Jan M. Pawlowski \\ Ruhr West University of Applied \\ Sciences \\ Mülheim \\ Germany \\ Prof. Dr. Markus Bick ( $\varangle)$ \\ Malte Martensen, M.Sc. \\ ESCP Europe Business School Berlin \\ Heubnerweg 8-10 \\ 14059 Berlin \\ Germany \\ mbick@escpeurope.eu}

Prof. Dr. René Peinl

Hof University of Applied Sciences

Hof

Germany

Dr. Stefan Thalmann

Prof. Dr. Ronald Maier

University of Innsbruck

Innsbruck

Austria

Dipl.-Wirt.-Inf. Paul Kruse

Dipl.-Wirt.-Inf. Lars Hetmank

TU Dresden

Dresden

Germany

Henri Pirkkalainen, M.Sc.

University of Jyväskylä

Jyväskylä

Finland

Received: 2013-03-10

Accepted: 2013-12-05

Accepted after three revisions by Professors Bichler, Hess, Krishnan, and Loos.

Published online: 2014-02-20
This article is also available in German in print and via http://www. wirtschaftsinformatik.de: Pawlowski JM, Bick $M$, Peinl R, Thalmann $S$, Maier $R$, Hetmank L, Kruse $P$, Martensen M, Pirkkalainen H (2014) Soziale Wissensumgebungen. WIRTSCHAFTSINFORMATIK. doi: 10.1007/ s11576-014-0409-3.

\section{Electronic Supplementary Material The online version of this article (doi: 10.1007/s12599-014-0318-4) contains supplementary material, which is available to authorized users.}

(C) Springer Fachmedien Wiesbaden 2014

\section{Introduction}

Social software has changed research and practice in the knowledge management (KM) field (von Krogh 2012). Several current trends and research issues offer a new understanding of how social software has changed this research field, as well as how scholars in business and information systems engineering (BISE) should take up this emerging research field. The present article offers a review of such trends and a framework for addressing the remaining issues.

For the past several decades, information systems (IS) scholars and practitioners alike have been studying KM (Heisig 2009; Holsapple and Joshi 2002; Lee and Chen 2012; Serenko et al. 2010). Many KM system functionalities (Alavi and Leidner 2001) have offered the promise of improving how organizations handle knowledge (Maier 2007). However, the actual results rarely achieve the exaggerated outcomes promised by the vast hype over KM (Heisig 2009; Serenko et al. 2010). More recently, social software (Hippner and Wilde 2005; Richter et al. 2011) has prompted renewed expectations for the ways in which technology might help organizations improve their KM - backed up by global success stories that feature hundreds of millions of users (e.g., Facebook). Since the productivity of knowledge workers also remains a critical challenge for organizations (Drucker 1994), social software has had a notable influence on KM research and practice (Avram 2006; Hemsley and Mason 2013; Zheng et al. 2010).

Research into social software has adopted social, organizational, and technical perspectives, such as studies of the adoption of technology across different generations (Kaplan and Haenlein 2010), management of social applications (Brambilla et al. 2012), collaboration in distributed teams (Oshri et al. 2008), or the security and reliability of enabling technologies (Kärkkäinen et al. 2010). From a methodological standpoint, this research is diverse, featuring qualitative, quantitative, analytical, and constructive methods (Wallace et al. 2011). Furthermore, market trends have increased the availability of various collaboration infrastructures to employees, such as MS SharePoint, Lotus Notes, Jive, or Liferay. Global, distributed organizations thus have new tools to manage their knowledge-intensive processes. However, social software also raises new questions: How does it alter the KM practices in organizations? How can organizations design and manage their environment by adopting the new breed of software to ensure they function in social knowledge environment that comprises concepts, methods, and tools that benefit KM purposes? (see definition in Sect. 3.1).

No extant research has addressed the extent to which the IS discipline can contribute to a clearer understanding of the 


\section{Social Knowledge Environments}

Jan M. Pawlowski, Markus Bick, Paul Kruse, Lars Hetmank, Stefan Thalmann, Henri Pirkkalainen, Malte Martensen, René Peinl, Eric Schoop, Ronald Maier

Business \& Information System Engineering (2014) 6 (2)

Appendix (available online via http://link.springer.com) 


\section{Appendix}

We limited the search population to journal papers and peer-reviewed conference proceedings, as they provide the necessary rigor and quality in scientific research. With respect to search resources, we included all databases that were accessible through the library subscriptions of the institutions with which the authors have been affiliated: ACM Digital Library, Ebscohost (Academic Search Complete and Business Source Complete), Emerald, IEEE Xplore Digital Library, Sage Journals, ScienceDirect, SpringerLink, Web of Knowledge, and Wiley. We searched all resources between 2000 and 2012; the review took place in 2012. The exception is the legal perspective, which we conducted in response to a reviewer's request in 2013, so it included papers published in 2013. The search terms were applied to title and abstract, not the full text, which helped reduce blurring and limited the results to a reasonable number. The restriction to empirical research reduced the number of results from 450 to about 60 in IEEE. Table A1 shows the search terms representing each of the dimensions raised in Section 1 and detailed as key areas of research, as described next.

Tab. A1 Review dimensions and search terms

\begin{tabular}{|c|c|}
\hline Dimension (key area of research) & Search term \\
\hline $\begin{array}{l}\text { Social and cultural dimension } \\
\text { (Social software for knowledge } \\
\text { management) }\end{array}$ & $\begin{array}{l}\text { (“enterprise social” OR “knowledge management” OR } \\
\text { "knowledge sharing”) AND } \\
\text { (“social software” OR “social media” OR “web 2.0” OR } \\
\text { bookmarking OR “social networking” OR blogging OR “micro- } \\
\text { blogging” OR wiki OR “collaborative writing”) AND } \\
\text { (survey OR case study) }\end{array}$ \\
\hline $\begin{array}{l}\text { Organizational and contextual } \\
\text { dimension } \\
\text { (Support of for distributed organizations } \\
\text { in knowledge-intensive settings) }\end{array}$ & $\begin{array}{l}\text { (team*OR group*) AND } \\
\text { (distribut* OR virtual* OR dispers*) AND } \\
\text { ((ICT OR IT) OR (information* OR knowledge*)) }\end{array}$ \\
\hline $\begin{array}{l}\text { Technical } \\
\text { (Standards and interoperability) }\end{array}$ & $\begin{array}{l}\text { ("knowledge management" OR “knowledge sharing”) AND } \\
\text { (interoperability OR standard) }\end{array}$ \\
\hline $\begin{array}{l}\text { Legal dimension } \\
\text { (Data protection and legal aspects) }\end{array}$ & $\begin{array}{l}\text { (“social media” OR “social software”) AND } \\
\text { (“data protection” OR legal OR law) }\end{array}$ \\
\hline
\end{tabular}


Tab. A2 Barriers, interventions, and gaps for social software and knowledge management

\begin{tabular}{|c|c|c|c|}
\hline Topic/Barriers & $\begin{array}{l}\text { Interventions and Solutions/ } \\
\text { Limitations }\end{array}$ & Methods & Research Strand \\
\hline $\begin{array}{l}\text { Communication in } \\
\text { teams (Kärkkäinen et } \\
\text { al. 2010; Noll et al. } \\
\text { 2010; Zhao and Chen, } \\
\text { 2013) }\end{array}$ & $\begin{array}{l}\text { Current: Communication technology is } \\
\text { the most commonly cited approach to } \\
\text { overcome the geographic distance } \\
\text { problem. Use of social network analysis } \\
\text { to identify communication intensity. } \\
\text { Gaps: The provision of tools and services } \\
\text { does not guarantee success. Relation to } \\
\text { various other challenges and therefore, } \\
\text { persistent challenge to address. Process } \\
\text { and tools to activate team members, in } \\
\text { particular non-active users. }\end{array}$ & $\begin{array}{l}\text { Qualitative } \\
\text { empirical study } \\
\text { (interviews, } \\
\text { content } \\
\text { analysis), case } \\
\text { study, action } \\
\text { research, social } \\
\text { network analysis }\end{array}$ & $\begin{array}{l}\text { Social software, } \\
\text { cross-border KM }\end{array}$ \\
\hline $\begin{array}{l}\text { Productivity depends } \\
\text { on social } \\
\text { communication tools, } \\
\text { especially in large, } \\
\text { geographically } \\
\text { dispersed organizations } \\
\text { (Onyechi and } \\
\text { Abeysinghe 2009; } \\
\text { Ramasubbu et al. 2005) }\end{array}$ & $\begin{array}{l}\text { Current: Social communication improves } \\
\text { productivity only if processes are } \\
\text { sufficiently mature. Single sign-on for } \\
\text { different social media tools increases } \\
\text { adoption and user satisfaction. } \\
\text { Gaps: Lack of differentiation among } \\
\text { different social communication tools and } \\
\text { their functionality. }\end{array}$ & $\begin{array}{l}\text { Conceptual } \\
\text { study and } \\
\text { empirical } \\
\text { validation }\end{array}$ & $\begin{array}{l}\text { Semi-permeable } \\
\text { organization, social } \\
\text { software, cross- } \\
\text { border KM }\end{array}$ \\
\hline $\begin{array}{l}\text { Organizational support } \\
\text { in terms of training, } \\
\text { common practices, and } \\
\text { policies (Husin and } \\
\text { Hanisch 2011; Pallot et } \\
\text { al. 2010) }\end{array}$ & $\begin{array}{l}\text { Current: Trying to reach an understanding } \\
\text { of which mechanisms foster collaboration } \\
\text { and support the adoption of emerging } \\
\text { technologies and services, such as } \\
\text { creating an organizational policy for } \\
\text { social software. } \\
\text { Gaps: Identification of good practices and } \\
\text { instruments; successful adoption and } \\
\text { large-scale awareness not reached. }\end{array}$ & $\begin{array}{l}\text { Constructive } \\
\text { research, } \\
\text { qualitative } \\
\text { empirical study } \\
\text { (interview, } \\
\text { theoretical } \\
\text { mapping) }\end{array}$ & $\begin{array}{l}\text { Crowd knowledge, } \\
\text { semi-permeable } \\
\text { organization }\end{array}$ \\
\hline $\begin{array}{l}\text { Integration of social } \\
\text { software in other } \\
\text { information systems } \\
\text { (Millen et al. 2006) }\end{array}$ & $\begin{array}{l}\text { Current: Social software, such as wikis, } \\
\text { social networks, or bookmarking is not } \\
\text { integrated with enterprise search or } \\
\text { corporate directory. } \\
\text { Gaps: Many other integration scenarios, } \\
\text { such as integration with collaboration } \\
\text { tools and office software, must be } \\
\text { considered as well. }\end{array}$ & $\begin{array}{l}\text { Case study, } \\
\text { constructive } \\
\text { research with } \\
\text { field trial }\end{array}$ & Social software \\
\hline
\end{tabular}




\begin{tabular}{|c|c|c|c|}
\hline $\begin{array}{l}\text { Coupling of intranet } \\
\text { and Internet social } \\
\text { services (Müller } \\
\text { and Stocker 2011) }\end{array}$ & $\begin{array}{l}\text { Current: Intranet services are strictly } \\
\text { separated from the Internet, resulting in the } \\
\text { need for double posting or double monitoring } \\
\text { for employees. } \\
\text { Gaps: Identification of mechanisms that } \\
\text { easily allow employees to decide which } \\
\text { information may be published on the Internet, } \\
\text { according to privacy policies. }\end{array}$ & $\begin{array}{l}\text { Case study, } \\
\text { qualitative } \\
\text { empirical study }\end{array}$ & Social software \\
\hline $\begin{array}{l}\text { Reasons for sharing } \\
\text { or not sharing } \\
\text { knowledge using } \\
\text { social software } \\
\text { (Paroutis and Al } \\
\text { Saleh 2009) }\end{array}$ & $\begin{array}{l}\text { Current: Information overload and lack of } \\
\text { time increased, instead of reduced, by social } \\
\text { software. } \\
\text { Gaps: How new and advanced tools can } \\
\text { replace existing tools. }\end{array}$ & $\begin{array}{l}\text { Case study, } \\
\text { qualitative } \\
\text { empirical study }\end{array}$ & Social software \\
\hline $\begin{array}{l}\text { Lack of } \\
\text { authoritative } \\
\text { content in social } \\
\text { software (Dagenais } \\
\text { and Robillard 2010) }\end{array}$ & $\begin{array}{l}\text { Current: Readers do not know whether the } \\
\text { content is correct and authorized from the } \\
\text { respective authority. } \\
\text { Gaps: Balance between hurdle of } \\
\text { contributing and authoritativeness discussed, } \\
\text { but no feasible solution presented so far. }\end{array}$ & $\begin{array}{l}\text { Qualitative } \\
\text { empirical study } \\
\text { (exploratory } \\
\text { field study) }\end{array}$ & Social software \\
\hline $\begin{array}{l}\text { Ambivalent role of } \\
\text { awareness } \\
\text { mechanisms } \\
\text { (Treude and Storey } \\
\text { 2010) }\end{array}$ & $\begin{array}{l}\text { Current: Awareness mechanisms may be } \\
\text { used to create social pressure, which is a } \\
\text { major barrier to their adoption. } \\
\text { Gaps: Balance between strict data privacy } \\
\text { laws and benefits of extensive data collection } \\
\text { and analysis by software tools. }\end{array}$ & $\begin{array}{l}\text { Qualitative and } \\
\text { quantitative } \\
\text { empirical study }\end{array}$ & Social software \\
\hline $\begin{array}{l}\text { Tag reuse and } \\
\text { structure } \\
\text { (Storey et al. 2009) }\end{array}$ & $\begin{array}{l}\text { Current: Users demand a way to create } \\
\text { hierarchical tags. To further reuse, a } \\
\text { suggestion system may be used. } \\
\text { Gaps: Semantic web technologies to be used } \\
\text { to allow for more complex relations than } \\
\text { hierarchies, though still are not easy to use for } \\
\text { non-IT professionals. }\end{array}$ & $\begin{array}{l}\text { Multiple case } \\
\text { study, } \\
\text { qualitative } \\
\text { validation }\end{array}$ & Social software \\
\hline $\begin{array}{l}\text { Active blog users } \\
\text { benefit most from } \\
\text { the system (Jackson } \\
\text { et al. 2007) }\end{array}$ & $\begin{array}{l}\text { Current: Blog users benefit from getting } \\
\text { specialist knowledge and social connections. } \\
\text { Gaps: Amount of time spent blogging not } \\
\text { taken into account. }\end{array}$ & $\begin{array}{l}\text { Quantitative and } \\
\text { qualitative } \\
\text { empirical study } \\
\text { (survey) }\end{array}$ & Social software \\
\hline $\begin{array}{l}\text { Social bookmarking } \\
\text { helps expert } \\
\text { finding, community } \\
\text { building, } \\
\text { information } \\
\text { sharing, and } \\
\text { discovery } \\
\text { (Damianos et al. } \\
\text { 2007; DiMicco et } \\
\text { al. 2008; Pan and } \\
\text { Millen 2008) }\end{array}$ & $\begin{array}{l}\text { Current: Analysis mainly based on system } \\
\text { logs. Perceived benefits by users may differ } \\
\text { from judgment of the analyst. } \\
\text { Gaps: Bookmarking for teams or groups not } \\
\text { covered, though some teams want a team } \\
\text { account. }\end{array}$ & $\begin{array}{l}\text { Quantitative and } \\
\text { qualitative } \\
\text { empirical study } \\
\text { (survey) }\end{array}$ & Social software \\
\hline
\end{tabular}




\begin{tabular}{|c|c|c|c|}
\hline $\begin{array}{l}\text { Microblogging } \\
\text { enhances awareness } \\
\text { of other users' } \\
\text { activities and social } \\
\text { communication } \\
\text { (Barnes et al. 2010) }\end{array}$ & $\begin{array}{l}\text { Current: Short messages do not need a } \\
\text { character limit to work. } \\
\text { Gaps: Privacy protection is needed for } \\
\text { some communication. }\end{array}$ & $\begin{array}{l}\text { Quantitative and } \\
\text { qualitative } \\
\text { empirical study } \\
\text { (survey) }\end{array}$ & Social software \\
\hline $\begin{array}{l}\text { Microblogging } \\
\text { shows current topics } \\
\text { of discussion better } \\
\text { than a KM system } \\
\text { (Hoong et al. 2012) }\end{array}$ & $\begin{array}{l}\begin{array}{l}\text { Current: Text mining can extract } \\
\text { pommunication } \\
\text { microblogging. }\end{array} \\
\text { Gaps: Comparative studies of different } \\
\text { social media tools are missing. }\end{array}$ & $\begin{array}{l}\text { Quantitative and } \\
\text { qualitative } \\
\text { empirical study }\end{array}$ & Social software \\
\hline $\begin{array}{l}\text { Urgent requests for } \\
\text { help are better } \\
\text { answered when } \\
\text { social media } \\
\text { activities are used to } \\
\text { find the right experts } \\
\text { (Wiener et al. 2012) }\end{array}$ & $\begin{array}{l}\text { Current: Targeted automatic request } \\
\text { performs better than an untargeted one. } \\
\text { Gaps: Compare automatic targeting with } \\
\text { manual selection based on experts' finder } \\
\text { application. }\end{array}$ & $\begin{array}{l}\text { Quantitative } \\
\text { empirical study } \\
\text { (survey) }\end{array}$ & Social software \\
\hline $\begin{array}{l}\text { Social media needs } \\
\text { to support business } \\
\text { processes (Graupner } \\
\text { et al. 2012) }\end{array}$ & $\begin{array}{l}\text { Current: Social media tools are not used } \\
\text { as much as expected in the case examined, } \\
\text { due to missing business process support. } \\
\text { Gaps: No empirical evidence that } \\
\text { extensions of social media to support } \\
\text { business processes really increase usage } \\
\text { and value. }\end{array}$ & $\begin{array}{l}\text { Quantitative } \\
\text { empirical study } \\
\text { (survey) }\end{array}$ & $\begin{array}{l}\text { Semi-permeable } \\
\text { organization }\end{array}$ \\
\hline $\begin{array}{l}\text { Social media users } \\
\text { need feedback } \\
\text { (Brzozowski 2009; } \\
\text { Brzozowski et al. } \\
\text { 2009) }\end{array}$ & $\begin{array}{l}\text { Current: Feedback and managers' own } \\
\text { activity determine activity level of } \\
\text { employees in social networks. Perceived } \\
\text { IT support is a barrier. Social media tools } \\
\text { provide no automatic feedback regarding } \\
\text { reception of own postings. } \\
\text { Gaps: Automatic feedback mechanisms } \\
\text { need to be tested. }\end{array}$ & $\begin{array}{l}\text { Quantitative and } \\
\text { qualitative } \\
\text { empirical study } \\
\text { (survey) }\end{array}$ & Social software \\
\hline $\begin{array}{l}\text { Structured data can } \\
\text { be shared via social } \\
\text { networks (Geyer et } \\
\text { al. 2008) }\end{array}$ & $\begin{array}{l}\text { Current: Small lists with five items are } \\
\text { shared in the survey. } \\
\text { Gaps: Larger lists, as in SharePoint, could } \\
\text { be socially shared too. }\end{array}$ & $\begin{array}{l}\text { Quantitative and } \\
\text { qualitative } \\
\text { empirical study } \\
\text { (survey) }\end{array}$ & Social software \\
\hline $\begin{array}{l}\text { Language barriers } \\
\text { are an issue for } \\
\text { global cooperation } \\
\text { (Yu et al. 2011) }\end{array}$ & $\begin{array}{l}\text { Current: Automatic filtering based on } \\
\text { social and geographic criteria and } \\
\text { translation can help. } \\
\text { Gaps: Cultural differences must be } \\
\text { considered, as well as language. }\end{array}$ & $\begin{array}{l}\text { Qualitative } \\
\text { empirical study } \\
\text { (survey) }\end{array}$ & Cross-border KM \\
\hline
\end{tabular}


Tab. A3 Barriers, interventions and gaps for globally distributed teams

\begin{tabular}{|c|c|c|c|}
\hline Topic/Barriers & $\begin{array}{l}\text { Interventions and Solutions/ } \\
\text { Limitations }\end{array}$ & Methods & Research Strand \\
\hline $\begin{array}{l}\text { Trust and awareness } \\
\text { (Dubé and Robey } \\
\text { 2009; } \\
\text { Kanawattanachai and } \\
\text { Yoo 2007; Riege } \\
\text { 2005; Thomas and } \\
\text { Bostrom 2010a) }\end{array}$ & $\begin{array}{l}\text { Current: Mistrust can be instrumental to } \\
\text { build trust, but there is still a lack of } \\
\text { knowledge about how virtual teams } \\
\text { establish trust and trust another's } \\
\text { expertise. Trust and awareness building } \\
\text { require different instruments. } \\
\text { Gaps: Understand which effect IT has on } \\
\text { establishing trust and how functionality } \\
\text { needs to be designed to support it; new } \\
\text { instruments needed for building trust. }\end{array}$ & $\begin{array}{l}\text { Qualitative } \\
\text { empirical study } \\
\text { (interview, content } \\
\text { analysis), laboratory } \\
\text { experiment } \\
\text { (survey), grounded } \\
\text { theory }\end{array}$ & $\begin{array}{l}\text { Crowd knowledge, } \\
\text { Cross-border KM }\end{array}$ \\
\hline $\begin{array}{l}\text { Conflict (Thomas } \\
\text { and Bostrom 2010a; } \\
\text { Wakefield et al. } \\
\text { 2008) }\end{array}$ & $\begin{array}{l}\text { Current: Leadership roles and } \\
\text { collaboration technology can lower task, } \\
\text { process, and relationship conflict. } \\
\text { Gaps: Explore what IT functionality } \\
\text { impacts which kind of conflict type. }\end{array}$ & $\begin{array}{l}\text { Qualitative } \\
\text { empirical study } \\
\text { (interview, survey) }\end{array}$ & $\begin{array}{l}\text { Crowd knowledge, } \\
\text { Cross-border KM }\end{array}$ \\
\hline $\begin{array}{l}\text { IT support (Dubé and } \\
\text { Robey 2009; } \\
\text { Majchrzak et al. } \\
\text { 2005; Thomas and } \\
\text { Bostrom 2010a) }\end{array}$ & $\begin{array}{l}\text { Current: Distributed teams need to rely on } \\
\text { IT functionality that supports their tasks } \\
\text { by providing adequate contextual } \\
\text { information. They also need the } \\
\text { knowledge of how to use provided IT } \\
\text { functionality to best fit their tasks. } \\
\text { Gaps: Support the complex decision- } \\
\text { making process of what IT functionality } \\
\text { could be appropriate to fit a team's tasks } \\
\text { and how to use it. }\end{array}$ & $\begin{array}{l}\text { Qualitative } \\
\text { empirical study } \\
\text { (interview, content } \\
\text { analysis, survey), } \\
\text { grounded theory }\end{array}$ & Social software \\
\hline $\begin{array}{l}\text { Team members } \\
\text { (Dubé and Robey } \\
\text { 2009; } \\
\text { Kanawattanachai and } \\
\text { Yoo 2007; Oshri et } \\
\text { al. 2008; Robert et al. } \\
\text { 2008; Staples and } \\
\text { Webster 2008) }\end{array}$ & $\begin{array}{l}\text { Current: Team members need to be } \\
\text { selected carefully by considering } \\
\text { expertise or past working history. Over } \\
\text { time, team members establish norms, } \\
\text { rules, or procedures to coordinate their } \\
\text { team activities. Use of social network } \\
\text { analysis to identify communication } \\
\text { intensity. } \\
\text { Gaps: Understand the potential effects } \\
\text { when teams members come together and } \\
\text { identify with differing IT services. } \\
\text { Activating team members, in particular } \\
\text { non-active users. }\end{array}$ & $\begin{array}{l}\text { Qualitative } \\
\text { empirical study } \\
\text { (interview, content } \\
\text { analysis, case- } \\
\text { study, laboratory } \\
\text { experiment (survey) }\end{array}$ & $\begin{array}{l}\text { Semi-permeable } \\
\text { organization, } \\
\text { crowd knowledge }\end{array}$ \\
\hline
\end{tabular}




\begin{tabular}{|c|c|c|c|}
\hline $\begin{array}{l}\text { Team leaders } \\
\text { (Staples and } \\
\text { Webster 2008; } \\
\text { Thomas and } \\
\text { Bostrom 2010b; } \\
\text { Wakefield et al. } \\
\text { 2008) }\end{array}$ & $\begin{array}{l}\text { Current: Leaders in distributed teams } \\
\text { have various roles (e.g., facilitator, } \\
\text { coordinator, mentor) and need to rely on } \\
\text { team members' willingness and } \\
\text { knowledge to use technology for } \\
\text { teamwork. } \\
\text { Gaps: Support team leaders in assessing } \\
\text { the current state of the team's technology } \\
\text { knowledge to arrange for appropriate } \\
\text { facilitation interventions when necessary. }\end{array}$ & $\begin{array}{l}\text { Qualitative } \\
\text { empirical study } \\
\text { (survey, interview) }\end{array}$ & $\begin{array}{l}\text { Semi-permeable } \\
\text { organization }\end{array}$ \\
\hline $\begin{array}{l}\text { Coordination } \\
\text { processes (Dubé } \\
\text { and Robey 2009; } \\
\text { Kanawattanachai } \\
\text { and Yoo 2007; } \\
\text { Thomas and } \\
\text { Bostrom 2010b) }\end{array}$ & $\begin{array}{l}\text { Current: The coordination of team } \\
\text { members in distributed settings is } \\
\text { challenging without knowledge of which } \\
\text { strategies teams apply to coordinate their } \\
\text { work. } \\
\text { Gaps: Develop process and outcome } \\
\text { indicators to determine when team } \\
\text { members should meet to coordinate their } \\
\text { next steps. }\end{array}$ & $\begin{array}{l}\text { Qualitative } \\
\text { empirical study } \\
\text { (interview, content } \\
\text { analysis, laboratory } \\
\text { experiment, } \\
\text { survey), grounded } \\
\text { theory }\end{array}$ & $\begin{array}{l}\text { Crowd knowledge, } \\
\text { cross-border KM }\end{array}$ \\
\hline $\begin{array}{l}\text { Knowledge transfer } \\
\text { (Choi et al. 2010; } \\
\text { Oshri et al. 2008; } \\
\text { Robert et al. 2008; } \\
\text { Thomas and } \\
\text { Bostrom 2010b) }\end{array}$ & $\begin{array}{l}\text { Current: In distributed settings, the } \\
\text { transfer of knowledge is cumbersome } \\
\text { even though IT has advanced } \\
\text { considerably. However, other than } \\
\text { sharing knowledge, team members need } \\
\text { to apply knowledge to the problem at } \\
\text { hand. } \\
\text { Gaps: Explore the effects of single IT } \\
\text { functionality on knowledge sharing and } \\
\text { application. }\end{array}$ & $\begin{array}{l}\text { Qualitative } \\
\text { empirical study } \\
\text { (case study, } \\
\text { interviews), } \\
\text { laboratory } \\
\text { experiment (survey) }\end{array}$ & $\begin{array}{l}\text { Crowd knowledge, } \\
\text { Cross-border KM, } \\
\text { social software }\end{array}$ \\
\hline $\begin{array}{l}\text { Cultural diversity } \\
\text { (Hung 2008; Pallot } \\
\text { et al. 2010) }\end{array}$ & $\begin{array}{l}\text { Current: Cultural and diversity studies } \\
\text { integrated to KM domain by enriching } \\
\text { previous culture models and knowledge } \\
\text { on the subject. } \\
\text { Gaps: Development of KM-specific } \\
\text { culture models }\end{array}$ & $\begin{array}{l}\text { Qualitative } \\
\text { empirical study } \\
\text { (case study, } \\
\text { ethnographic } \\
\text { approach, field } \\
\text { experiment, } \\
\text { observation) }\end{array}$ & \\
\hline
\end{tabular}


Tab. A4 Barriers, interventions, and gaps for the technology perspective

\begin{tabular}{|c|c|c|c|}
\hline Topic/Barriers & $\begin{array}{l}\text { Interventions and Solutions/ } \\
\text { Limitations }\end{array}$ & Methods & Research Strand \\
\hline $\begin{array}{l}\text { Reliability and } \\
\text { security of } \\
\text { information } \\
\text { exchange } \\
\text { (Kärkkäinen et al. } \\
\text { 2010) }\end{array}$ & $\begin{array}{l}\text { Current: Focus primarily on technology } \\
\text { improvements, not on research. } \\
\text { Gaps: Mental mind-sets on social } \\
\text { software are often the main barrier, not } \\
\text { security threats. Further research into } \\
\text { issues of trust and intention to share } \\
\text { knowledge is required. }\end{array}$ & $\begin{array}{l}\text { Qualitative } \\
\text { empirical study } \\
\text { (literature study, } \\
\text { expert interview, } \\
\text { survey) }\end{array}$ & $\begin{array}{l}\text { Social software, } \\
\text { crowd knowledge }\end{array}$ \\
\hline $\begin{array}{l}\text { Privacy concerns } \\
\text { and handling of } \\
\text { sensitive } \\
\text { information } \\
\text { (Campisi et al. } \\
\text { 2009; Grace 2009) }\end{array}$ & $\begin{array}{l}\text { Current: Formalization of guidelines and } \\
\text { best practices, relying on a set of } \\
\text { principles, such as collecting data with the } \\
\text { knowledge and consent of the individual, } \\
\text { specifying the purpose of the data, and } \\
\text { protecting the data against misuse. } \\
\text { Gaps: Understanding of the purpose of the } \\
\text { social software tool is often lacking. } \\
\text { Privacy concerns often needless. }\end{array}$ & $\begin{array}{l}\text { Qualitative } \\
\text { empirical study } \\
\text { (literature study, } \\
\text { interview) }\end{array}$ & $\begin{array}{l}\text { Social software, } \\
\text { crowd knowledge }\end{array}$ \\
\hline $\begin{array}{l}\text { Interoperability } \\
\text { between diverse } \\
\text { information systems } \\
\text { (Jung 2012; van } \\
\text { Wamelen and de } \\
\text { Kool 2008) }\end{array}$ & $\begin{array}{l}\text { Current: A lack of technical standards } \\
\text { makes knowledge sharing and semantic } \\
\text { interoperability difficult. } \\
\text { Gaps: Overall strategy for the tools is } \\
\text { often missing from the integration } \\
\text { process. }\end{array}$ & $\begin{array}{l}\text { Qualitative } \\
\text { empirical study } \\
\text { (literature analysis, } \\
\text { field experiment) }\end{array}$ & Social software \\
\hline $\begin{array}{l}\text { Interoperability of } \\
\text { different } \\
\text { vocabularies (Lei } \\
\text { Zheng and Mai } \\
\text { Chan 2004) }\end{array}$ & $\begin{array}{l}\text { Current: Direct mapping, leaf-node } \\
\text { linking, and other methods applied in } \\
\text { some cases. } \\
\text { Gaps: Adopt the idea of the linked open } \\
\text { data project within enterprises. }\end{array}$ & $\begin{array}{l}\text { Qualitative } \\
\text { empirical study } \\
\text { (literature study) }\end{array}$ & Social software \\
\hline $\begin{array}{l}\text { Knowledge } \\
\text { integration and re- } \\
\text { use (Happel et al. } \\
\text { 2008; Kamsu } \\
\text { Foguem et al. 2008) }\end{array}$ & $\begin{array}{l}\text { Current: Exchange of experiences or } \\
\text { feedback through lessons learned or } \\
\text { artifact documentation. } \\
\text { Gaps: Introduction of standard } \\
\text { vocabulary for case descriptions. }\end{array}$ & $\begin{array}{l}\text { Qualitative } \\
\text { empirical study } \\
\text { (literature study), } \\
\text { conceptual study } \\
\text { (prototype } \\
\text { development) }\end{array}$ & $\begin{array}{l}\text { Semi-permeable } \\
\text { organization }\end{array}$ \\
\hline $\begin{array}{l}\text { Contextual } \\
\text { enrichment (Gupta } \\
\text { and Seshasai 2007; } \\
\text { Nunes et al. 2009) }\end{array}$ & $\begin{array}{l}\text { Current: Ontology-based representation } \\
\text { of contextual information and recording. } \\
\text { Gaps: Analyze cost considerations with } \\
\text { introduction and maintenance of } \\
\text { ontology-based environments. }\end{array}$ & $\begin{array}{l}\text { Conceptual study } \\
\text { (prototype } \\
\text { development), case } \\
\text { study }\end{array}$ & $\begin{array}{l}\text { Cross-border KM, } \\
\text { crowd knowledge }\end{array}$ \\
\hline
\end{tabular}


Tab. A5 Barriers, interventions and gaps for the legal perspective

\begin{tabular}{|c|c|c|c|}
\hline Topic/Barriers & $\begin{array}{l}\text { Interventions and Solutions/ } \\
\text { Limitations }\end{array}$ & Methods & Research Strand \\
\hline $\begin{array}{l}\text { Challenges for } \\
\text { knowledge } \\
\text { protection in social } \\
\text { media (Väyrynen et } \\
\text { al. 2013) }\end{array}$ & $\begin{array}{l}\text { Current: Organizations lack knowledge } \\
\text { protection and security-oriented KM } \\
\text { processes related to social media. } \\
\text { Gaps: Creation of KM and protection } \\
\text { strategies for KM; finding a balance } \\
\text { between knowledge sharing and } \\
\text { knowledge protection strategies. }\end{array}$ & $\begin{array}{l}\text { Qualitative } \\
\text { empirical study, } \\
\text { (interviews) case } \\
\text { study }\end{array}$ & Social software \\
\hline $\begin{array}{l}\text { Knowledge } \\
\text { protection in } \\
\text { innovation } \\
\text { management } \\
\text { (Olander et al. 2011) }\end{array}$ & $\begin{array}{l}\text { Current: Organizations lack a systematic } \\
\text { knowledge-protection strategy. } \\
\text { Gaps: Additional research on efficient } \\
\text { knowledge-protection mechanisms in } \\
\text { diverse organizations, cultures, and } \\
\text { legal environments to preserve core } \\
\text { knowledge and prevent competitors } \\
\text { from imitating are required. }\end{array}$ & $\begin{array}{l}\text { Qualitative } \\
\text { empirical study } \\
\text { (literature study), } \\
\text { case study }\end{array}$ & $\begin{array}{l}\text { Semi-permeable } \\
\text { organization }\end{array}$ \\
\hline $\begin{array}{l}\text { Organizational risk } \\
\text { management and IT } \\
\text { security management } \\
\text { (Manhart and } \\
\text { Thalmann 2013) }\end{array}$ & $\begin{array}{l}\text { Current: Organizational risk } \\
\text { management relies on data protection. } \\
\text { Gaps: Risk management should also } \\
\text { focus on knowledge protection. } \\
\text { Integration of IS security management, } \\
\text { performance management, and KM. }\end{array}$ & $\begin{array}{l}\text { Qualitative } \\
\text { empirical study } \\
\text { (literature study; } \\
\text { research in } \\
\text { progress) }\end{array}$ & Cross-border KM \\
\hline $\begin{array}{l}\text { Legal aspects hinder } \\
\text { research in social } \\
\text { intranets (Dolog et } \\
\text { al. 2009) }\end{array}$ & $\begin{array}{l}\text { Current: Mainly data from social } \\
\text { communities in the open Web are } \\
\text { analyzed. } \\
\text { Gaps: Analyzing data from enterprise } \\
\text { social software. }\end{array}$ & $\begin{array}{l}\text { Literature and } \\
\text { expert interviews }\end{array}$ & Social software \\
\hline $\begin{array}{l}\text { Trust in enterprise } \\
\text { microblogging } \\
\text { networks (Chelmis } \\
\text { and Prasanna 2013) }\end{array}$ & $\begin{array}{l}\text { Current: Research uses trust as an } \\
\text { indicator for expertise in enterprises. } \\
\text { Gaps: Research of trust that implies not } \\
\text { exploiting newly acquired knowledge } \\
\text { for malicious deeds. }\end{array}$ & $\begin{array}{l}\text { Quantitative } \\
\text { empirical analysis }\end{array}$ & Social software \\
\hline $\begin{array}{l}\text { Social networks } \\
\text { derived from } \\
\text { enterprise e-mail } \\
\text { data (Lin et al. 2012) }\end{array}$ & $\begin{array}{l}\text { Current: In certain circumstances, } \\
\text { intranet data can be collected legally. } \\
\text { Gaps: Develop a commonly accepted } \\
\text { method for collecting data in enterprises } \\
\text { without violating laws. }\end{array}$ & $\begin{array}{l}\text { Quantitative } \\
\text { empirical analysis }\end{array}$ & Cross-border KM \\
\hline
\end{tabular}




\section{References Appendix}

Barnes SJ, Bohringer M, Kurze C, Stietzel J (2010) Towards an understanding of social software: the case of Arinia. In: Proc 43rd Hawaii international conference on system sciences (HICSS), pp 1-9

Brzozowski MJ (2009) WaterCooler: exploring an organization through enterprise social media. In: Proc ACM 2009 international conference on supporting group work, pp 219-228

Brzozowski MJ, Sandholm T, Hogg T (2009) Effects of feedback and peer pressure on contributions to enterprise social media. In: Proc ACM 2009 international conference on supporting group work, pp 61-70

Campisi P, Maiorana E, Neri A (2009) Privacy protection in social media networks a dream that can come true? In: Proc 16th international conference on digital signal processing (DSP’09), New Jersey, pp 254-258

Chelmis C, Prasanna VK (2013) An empirical analysis of microblogging behavior in the enterprise. Social Network Analysis and Mining 3(3):611-633

Choi SY, Lee H, Yoo Y (2010) The impact of information technology and transactive memory systems on knowledge sharing, application, and team performance: a field study. MIS Quarterly 34(4):855-870

Dagenais B, Robillard MP (2010) Creating and evolving developer documentation: understanding the decisions of open source contributors. In: Proc 18th ACM SIGSOFT international symposium on foundations of software engineering (FSE'10), New York, pp 127-136. doi:10.1145/1882291.1882312

Damianos LE, Cuomo D, Griffith J., Hirst DM, Smallwood J (2007) Exploring the adoption, utility, and social influences of social bookmarking in a corporate environment. In: Proc 40th Hawaii international conference on system sciences, pp 86-86

DiMicco J, Millen DR, Geyer W, Dugan C, Brownholtz B, Muller M (2008) Motivations for social networking at work. In: Proc ACM 2008 conference on computer supported cooperative work (CSCW’08), San Diego, pp 711-720

Dolog P, Krötzsch M, Schaffert S, Vrandcic D (2009) Social web and knowledge management. In: King I, Baeza-Yates R (eds) Weaving services and people on the world wide web. Springer, Berlin, pp 217-227

Dubé L, Robey D (2009) Surviving the paradoxes of virtual teamwork. Information Systems Journal 19(1):3-30. doi:10.1111/j.1365-2575.2008.00313.x

Geyer W, Dugan C, DiMicco J, Millen DR, Brownholtz B, Muller, M (2008) Use and reuse of shared lists as a social content type. In: Proc SIGCHI conference on human factors in computing systems, pp 1545-1554

Grace TPL (2009) Wikis as a knowledge management tool. Journal of Knowledge Management 13(4):64-74. doi:10.1108/13673270910971833

Graupner S, Bartolini C, Motahari H, Mirylenka D (2012) When social media meet the enterprise. In: Proc 16th IEEE international conference enterprise distributed object computing (EDOC), pp 201-210

Gupta A, Seshasai, S (2007) 24-hour knowledge factory: using internet technology to leverage spatial and temporal separations. ACM Transactions on Internet Technology (TOIT) 7(3):14 
Happel HJ, Maalej W, Stojanovi L (2008) Team: towards a software engineering semantic web. In: Proc 2008 international workshop on cooperative and human aspects of software engineering, pp 57-60

Hoong ALS, Lim TM, Leow SK, Aun JLR (2012) A study on the use of "Yams" for enterprise knowledge sharing. In: Proc 2nd international conference on digital information and communication technology and it's applications (DICTAP), pp 183-188

Hung YC (2008) The impact of cultural diversity on global virtual team collaboration Asocial identity perspective. In: Proc 41st Hawaii international conference on system sciences (HICSS’08), Big Island, pp 1-10. doi:10.1109/HICSS.2008.441

Husin M, Hanisch J (2011) Utilising the social media and organisation policy (Someop) framework: an example of organisational policy development within a public sector entity. In: Proc 19th European conference on information systems - ICT and Sustainable service development (ECIS’11), Helsinki

Jackson A, Yates J, Orlikowski W (2007) Corporate blogging: building community through persistent digital talk. In: Proc 40th Hawaii international conference on system sciences (HICSS), pp 80-80

Jung JJ (2012) Semantic annotation of cognitive map for knowledge sharing between heterogeneous businesses. Expert Systems with Applications. 39(5):5857-5860. doi:10.1016/j.eswa.2011.11.082

Kamsu Foguem B, Coudert T, Béler C, Geneste L (2008) Knowledge formalization in experience feedback processes: an ontology-based approach. Computers in Industry. 59(7):694-710. doi:10.1016/j.compind.2007.12.014

Kanawattanachai P, Yoo Y (2007) The impact of knowledge coordination on virtual team performance over time. MIS Quarterly 31(4):783-808

Kärkkäinen H, Jussila J, Väisänen J (2010) Social media use and potential in business-tobusiness companies' innovation. In: Proc 14th international academic MindTrek conference on envisioning future media environments (MindTrek '10), Tampere, pp 228236.doi:10.1145/1930488.1930536

Lei Zeng M, Mai Chan L (2004) Trends and issues in establishing interoperability among knowledge organization systems. Journal of the American Society for Information Science and Technology. 55(5):377-395. doi:10.1002/asi.10387

Lin CY, Wu L, Wen Z, Tong H, Griffiths-Fisher V, Shi L, Lubensky D (2012) Social network analysis in enterprise. In: Proc IEEE. 100(9):2759-2776. doi:10.1109/JPROC.2012.2203090

Majchrzak A, Malhotra A, John R (2005) Perceived individual collaboration know-how development through information technology? Enabled contextualization: evidence from distributed teams. Information Systems Research 16(1):9-27. doi:10.1287/isre.1050.0044

Manhart M, Thalmann S (2013) An integrated risk management framework: measuring the success of organizational knowledge protection. In: Proc 19th Americas conference on information systems. Chicago, Illinois. Roundtable presentation 7

Millen, DR, Feinberg, J, Kerr, B (2006) Dogear: Social bookmarking in the enterprise. In: Proc SIGCHI conference on human factors in computing systems, pp 111-120

Müller J, Stocker A (2011) Enterprise microblogging for advanced knowledge sharing: the References@BTcase study. Journal of Universal Computer Science 17(4):532-547 
Noll J, Beecham S, Richardson I (2010) Global software development and collaboration: barriers and solutions. ACM Inroads 1(3):66-78. doi:10.1145/1835428.1835445

Nunes VT, Santoro FM, Borges MRS (2009) A context-based model for knowledge management embodied in work processes. Information Science 179(15):2538-2554. doi:10.1016/j.ins.2009.01.033

Olander H, Hurmelinna-Laukkanen P, Heilmann P (2011) Do SMEs benefit from HRMrelated knowledge protection in innovation management? International Journal of Innovation Management 15(3):593-616

Onyechi GC, Abeysinghe G (2009) Adoption of web based collaboration tools in the enterprise: challenges and opportunities. In: Proc international conference on current trends in information technology (CTIT), pp 1-6

Oshri I, van Fenema P, Kotlarsky J (2008) Knowledge transfer in globally distributed teams: the role of transactive memory. Information Systems Journal 18(6):593-616. doi:10.1111/j.1365-2575.2007.00243.x

Pallot M, Martínez-Carreras MA, Prinz W (2010) Collaborative distance. International Journal of e-Collaboration 6(2):1-32. doi:10.4018/jec.2010040101

Pan YX, Millen DR (2008) Information sharing and patterns of social interaction in an enterprise social bookmarking service. In: Proc 41st Hawaii international conference on system sciences, pp 158-158

Paroutis S, Al Saleh A (2009) Determinants of knowledge sharing using Web 2.0 technologies. Journal of Knowledge Management 13(4):52-63

Ramasubbu N, Krishnan MS, Kompalli P (2005) Leveraging global resources: a process maturity framework for managing distributed development. Software 22(3):80-86

Riege A (2005) Three-dozen knowledge-sharing barriers managers must consider. Journal of Knowledge Management 9(3):18-35. doi:10.1108/13673270510602746

Robert LP, Dennis AR, Ahuja MK (2008) Social capital and knowledge integration in digitally enabled teams. Information Systems Research 19(3):314-334. doi:10.1287/isre.1080.0177

Staples DS, Webster J (2008) Exploring the effects of trust, task interdependence and virtualness on knowledge sharing in teams. Information Systems Journal 18(6):617-640. doi:10.1111/j.1365-2575.2007.00244.x

Storey MA, Ryall J, Singer J, Myers D, Cheng LT, Muller M (2009) How software developers use tagging to support reminding and refinding. IEEE Transactions on Software Engineering 35(4):470-483

Thomas DM, Bostrom RP (2010a) Team leader strategies for enabling collaboration technology adaptation: team technology knowledge to improve globally distributed systems development work. European Journal of Information Systems 19(2):223-237. doi:10.1057/ejis.2010.14

Thomas DM, Bostrom RP (2010b) Vital signs for virtual teams: an empirically developed trigger model for technology adaptation interventions. MIS Quarterly 34(1):115-142

Treude C, Storey M (2010) Awareness 2.0: staying aware of projects, developers and tasks using dashboards and feeds. In: Proc 32nd international conference on software engineering, pp 365-374 
vanWamelen J, de Kool D (2008) Web 2.0: a basis for the second society? In: Proc of the 2nd international conference on theory and practice of electronic governance (ICEGOV'08), Cairo, pp 349-354

Väyrynen, K, Hekkala R, Liias T (2013) Knowledge protection challenges of social media encountered by organizations. Journal of Organizational Computing and Electronic Commerce 23(1):34-55

Wakefield RL, Leidner DE, Garrison G (2008) Research note - a model of conflict, leadership, and performance in virtual teams. Information Systems Research 19(4):434455. doi:10.1287/isre.1070.0149

Wiener C, Acquah IN, Heiss M, Mayerdorfer T, Langen M, Kammergruber WC (2012) Targeting the right crowd for corporate problem solving - Siemens case study with TechnoWeb 2.0. In: Proc IEEE international technology management conference (ITMC), pp 239-247

Yu CH, Thom-Santelli J, Millen D (2011) Enhancing blog readability for non-native English readers in the enterprise. In: Proc 2011 annual conference extended abstracts on human factors in computing systems, pp 1765-1770

Zhao RY, Chen BK (2013) Study on enterprise knowledge sharing in ESN perspective: a Chinese case study. Journal of Knowledge Management 17(3):416-434 
development of social knowledge environments. In the face of this gap, we propose a consideration of four categories of challenges (Pirkkalainen and Pawlowski 2013):

1. Social and cultural dimensions, such as challenges related to individual and group behavior, in particular culturally specific behaviors (e.g., Ågerfalk et al. 2005; Leidner et al. 2006; Pallot et al. 2010). We focus on the implications of enterprise social software for differences across cultures and borders as the use of social software and knowledge exchange differs strongly depending on cultural aspects (Pirkkalainen and Pawlowski 2013).

2. Organizational and contextual dimensions, including challenges tied to a particular context, organization, organizational unit, project, process management, or task (e.g., Avram 2006; Brambilla et al. 2012; DiMicco et al. 2008; Levy 2009; Zheng et al. 2010).

3. Technical dimensions, related to the adoption of technologies and their use in organizations (e.g., Onyechi and Abeysinghe 2009).

4. Knowledge protection and legal dimensions, such as the potential loss of knowledge, privacy, and filtering of offensive or illegal contents (e.g Alstete 2003; Väyrynen et al. 2013).

On the basis of this categorization, we analyze several key questions related to potential research areas, which we derive from a structured literature review of BISE/IS-related research. What barriers and challenges do knowledge workers face when collaborating globally through social software? What gaps persist in the IS discipline's knowledge base with respect to these barriers and challenges? What solutions have been proposed? Our initial answers to these questions lead to a proposed research agenda with four strands. We also note the contributions and methodological considerations that the BISE/IS community needs to address.

\section{Procedure}

We conducted a structured literature review (SLR) to determine the barriers, limitations, and current trends related to social knowledge environments. Following the principles of SLR (Webster and Watson 2002), our repeatable, wellstructured procedure sought to identify, evaluate, and interpret relevant literature for our research aim. Through our search strategy, we defined the search population, resources, and terms, as well as inclusion and exclusion criteria (online Appendix Table A1; all appendices available online via http://link.springer.com). The SLR consisted of two steps. First, we reviewed the abstracts, introductions, and conclusions of all articles found through an initial search to identify relevant studies. This approach is appropriate for information technology and software engineering literature, because the abstracts of articles in these fields tend to be insufficient, so we cannot rely solely on them (Brereton et al. 2007). Second, we analyzed the articles we identified as relevant in the first step, according to the barriers they address, the interventions and solutions they provide, and the scientific methods they apply. Thus, we classified mainstream (highly discussed), emerging, and immature topic areas (cf. Lee and Chen 2012). This categorization resulted from a collaborative research process among the coauthors: After agreeing on an initial categorization, we separated into four research teams, each of which determined categorizations of the topics, barriers, solutions, and interventions for different subsets of the corpus. In addition, we discussed our assignments during synchronous video conferences and mapped the identified barriers and research gaps. After three categorization cycles, both within teams and during plenary sessions, we identified current research strands as the result of the process, which then led to our research agenda.

\section{Social Knowledge Environments: Analysis Results}

In this section, we consider knowledge barriers and research gaps from social (Sect. 3.1), organizational (Sect. 3.2), technical (Sect. 3.3), and legal (Sect. 3.4) perspectives, for each research area identified in our analysis. These discussions combine to derive our research agenda, including a discussion of methods (Sect. 3.5). Detailed results are available in the Appendix.

\subsection{Social Software for Knowledge Management}

Social software represents the new hope of KM (Jackson 2010; von Krogh 2012). It comprises systems that are based on Internet technology; that support the monitoring of peripheral activity and that enable many-to-many communications (Cook 2008). Various terms serve to refer to this new, quickly growing phenomenon, including social media (Kaplan and Haenlein 2010) and usergenerated content (Cha et al. 2007). Regardless of the name, its development is evident in the increasing popularity and usage statistics surrounding social networks, blogs, wikis, and mediasharing platforms, which in turn result in vast amounts of noisy, distributed, unstructured, and dynamic data (Gundecha and Liu 2012). Furthermore, challenges emerge regarding strategic as well as process management solutions in these settings (Brambilla et al. 2012; von Krogh 2012). In addition, some consensus indicates that social software is not only a technological but also an ideological phenomenon, that is, "a group of Internetbased applications that build on the ideological and technological foundations of Web 2.0, and that allow the creation and exchange of User Generated Content" (Kaplan and Haenlein 2010, p. 61). In adaptive structuration terms, it entails not just technological affordances (Markus and Silver 2008) but also attitudes toward the technology (DeSanctis and Poole 1994) and the spirit of using this new breed of software. Building on the definitions of enterprise knowledge infrastructure (Maier et al. 2009) and KM system (Alavi and Leidner 2001), we propose that a social knowledge environment is defined as a comprehensive arrangement of information and communication technology (ICT) applications that are contextualized and integrated. Based on a shared ontology, they at least foster awareness of others' activities, encourage contributions of usergenerated content, and support networking for knowledge processes that seek to increase the performance of knowledge work. Social software also has shifted our understanding of KM to include informal, bottom-up, interest-driven practices performed by engaged individuals who are well connected in distributed, diverse, dynamic social constellations.

We identified 17 key barriers in our SLR, ranging from societal challenges and organizational issues to barriers for specific social software applications. Social software should run publicly on the Internet; it becomes more useful due to network effects (O'Reilly 2005). However, usage practices also depend on national and organizational cultures (Leidner et al. 2006). Moreover, adoption and 
interoperability processes are critical as software dominates particular contexts. As organizations seek to avoid publicly sharing their core knowledge (Müller and Stocker 2011), knowledge protection limits the use of social media in organizations (Väyrynen et al. 2013). Therefore, we concentrated our research on enterprise social software (Richter et al. 2011) that runs within company firewalls.

Technical gaps also include extraction of information from social knowledge environments, transformation of social data into searchable documents, their transmission to partners without permanent Internet access, and freezing of information that has been distributed across several systems for further refinement. These gaps can hinder knowledge maturation (Barnes et al. 2009). To trace the complex process of collaboratively creating knowledge in social knowledge environments, various initiatives have arisen, such as activity streams (Peinl et al. 2013). We provide a detailed list of these challenges and barriers in Table A2 in the online Appendix.

\subsection{Support for Distributed Organizations in Knowledge-Intensive Settings}

As more organizations rely on distributed settings for their work, KM serves an increasingly crucial role, particularly in domains that require frequent knowledge exchanges, such as global software development (Noll et al. 2010). The coordination of team activities and interactions in teams are well-known pitfalls (Thomas and Bostrom 2010) that result in decreased satisfaction and performance (Schweitzer and Duxbury 2010). We thus identified eight key barriers and related interventions: characteristics of team members and team leaders, provision of IT support, coordination, knowledge transfer, trust, conflict, and cultural diversity.

Distributed teams depend on the availability of IT, but they often can rely only on a specific set of provided functionalities, some of which do not fit their tasks. It is important to specify the knowledge context, especially if it is transferred through IT (Majchrzak et al. 2005). However, we lack knowledge about which strategies team members apply to coordinate their knowledge (Kanawattanachai and Yoo 2007), even though we find that team members often fail to integrate shared knowledge (Choi et al. 2010). Several studies emphasize the need to select team members carefully to create open, decentralized communication patterns but also establish procedures, standards, and templates for codifying information (Oshri et al. 2008), which can hamper the formation of subgroups (Staples and Webster 2008). We also lack a good understanding of how to design processes and collaboration technology that can adapt easily to team norms and patterns, or how to maintain dynamic relations across the people who participate in multiple teams with social knowledge environments. In addition, team leaders need assistance to improve knowledge transfer (Staples and Webster 2008) and assess a team's technology knowledge (Thomas and Bostrom 2010) if they are to arrange appropriate facilitation interventions. The challenges and barriers in this field appear in Table A3 in the online Appendix.

\subsection{Standards and Interoperability}

Standards are key for IT/IS (Krcmar 2005) because they help organizations in varied activities, such as migrating from an old to a new system (Haller 2009), interchanging data with business partners (Jung 2011), accessing systems from different devices and client software (Yu et al. 2008), or integrating systems to harness their data relations (Lei Zeng and Mai Chan 2004). The market of enterprise social software seems dominated by closed source solutions offered by large vendors (Drakos et al. 2012), with a lack of interoperability. We identified six main barriers in our SLR that reflect a technology perspective, ranging from general integration issues to specific challenges, such as knowledge contextualization.

Few standards are available for enterprise integration in general (Panetto and Molina 2008) and social software or the exchange of social data in particular (Peinl et al. 2013). Current data exchange strategies rely on the prerequisite that every participant has online access to the same social software installation. Without this access, the necessary information must be collected from internal systems, transformed into a document, and provided to the partner; alternatively, employees could use different platforms, depending on the team members with whom they want to share information with. However, interoperability generates additional complexity
(Kamsu Foguem et al. 2008). Consequently, formal, ontology-based experience feedback is required to cope with that challenge. Special attention should be paid to capturing the experience, as well as its context, because a shared view of context is crucial for knowledge sharing (Nunes et al. 2009). If it is possible to derive at least some part of the context automatically, such as in a software development environment, semantic recommendations can support users (Happel et al. 2008). However, no standard exists for exchanging these semantic context descriptions; therefore, every team member has to use the same tool to benefit from such recommendations. This approach also might be used in various settings. For example, with composite persona (Gupta and Seshasai 2007), extensive recordings of users' activities in so-called knowledge events help people on different continents or time zones take over the work. This method raises privacy concerns though (Campisi et al. 2009), and the exchange of context information across organizational boundaries requires secure communication channels to prevent eavesdropping (Kärkkäinen et al. 2010). A detailed list of these challenges and barriers appears in Table A4 in the online Appendix.

\subsection{Knowledge Protection and Legal Aspects}

The challenge of finding a balance between knowledge sharing and knowledge protection has been exacerbated by recent developments. Knowledge protection refers to a firm's efforts to maintain knowledge in its original and constructive state (Väyrynen et al. 2013). Even within an enterprise context, knowledge sharing occurs when devices can be used at home, in the workplace, during transportation periods, and in the course of leisure activities, such that they blur the borders between work and leisure, as well as between knowledge sharing for the individual or for the job (Väyrynen et al. 2013). To overcome these challenges, organizations need a holistic risk management approach that accounts for both data and the knowledge perspective (Manhart and Thalmann 2013; Bayer and Maier 2006). However, many organizations lack a clear or systematic knowledge protection strategy (Olander et al. 2011). Furthermore, social knowledge environments pose a challenge in terms of compliance with legal regulations, such as 
the Sarbanes-Oxley Act, Basel Accords, and so forth, in conjunction with privacy protection and equality laws (Otter 2007).

\subsection{Methods}

Social knowledge environments represent a relatively new research area, mainly investigated using exploratory, qualitative research methods. An overview how social software in organizations is currently investigated can be found in (Sect. 3.1 - online Appendix Table A2) Studies of social software beyond organizational boundaries mainly rely on (large) data sets, collected from social media. In distributed organizations (Sect. 3.2 - online Appendix Table A3), exploratory qualitative approaches are combined with grounded theory approaches, based on interviews and indepth data collection methods. In contrast, standardization studies (Sect. 3.3 - online Appendix Table A4) mainly refer to prior literature, with a few prototypical implementations. We find very few attempts applying design science research. Large-scale quantitative empiri$\mathrm{cal}$ research that seeks to test the theories or confirm results gathered from explorative research appear in the domain of distributed organizations, yet studies that operationalize team processes or team states during collaboration are scarce.

\section{Toward a Research Agenda for Social Knowledge Environments}

We have identified topics in social knowledge environments that we deemed helpful for both the BISE/IS academic community and professionals (Sect. 2; Appendix). Starting from these topics, we identified gaps across four topic areas (Sect. 3). Next, we clustered the barriers and possible solutions into four main research strands (vom Brocke et al. 2011), which we synthesized to cover most of the findings. Accordingly, we propose a research agenda that addresses main barriers, solution approaches, and methodological recommendations. Although necessarily incomplete, it provides a starting point for further development and discourse in the BISE/IS community.

\subsection{The Semi-Permeable Organization}

This concept refers to organizations that engage in practices spanning or crossing organizational boundaries, such as cooperating, crowdsourcing, applying flexible employment schemes, or participating in cross-organizational projects. It also encompasses IT practices such as consuming cloud services or allowing bring-your-own-device strategies. From an organizational perspective, softening these boundaries has both virtues and risks. Several findings have already indicated that social software can improve knowledge work, on local and global levels (Levy 2009; Zheng et al. 2010). Using social software helps blur organizational boundaries and diffuse knowledge more quickly. From a social perspective, openness and inter-organizational collaboration demand new mental mindsets and organizational change. So far KM mainly concentrated on the facilitation of sharing, while risks resulting from social knowledge environments and protective measures are widely neglected so far (Väyrynen et al. 2013). Furthermore, it is also recommended that organizations recreate organizational boundaries to rebuild the employees' awareness for risks of unwanted knowledge sharing (von Krogh 2012).

First, future research should focus on the investigation of risks related to sharing knowledge in social knowledge environments (von Krogh 2012). The next step from an empirical perspective would be to investigate the risks of engaging in social knowledge environments in more detail following the proposals from (Väyrynen et al. 2013) and (Jarvenpaa and Majchrzak 2010) for example. Finding a balance between strict privacy regulations and the need to harness insights by applying social network analysis to an extensive collection of social data in and beyond organizational boundaries also requires research from a legal perspective. From a design science perspective the next step should be to develop technical measures that help address such risks. One promising approach could be to adapt procedures from the domain of information security in this regard (Manhart and Thalmann 2013).

Second, future research should focus on the development of standards, such as those for context transfer, to facilitate interoperability between systems in relation to shared knowledge objects. Specifically, a standard for exchanging context information is needed; see Peinl et al. (2013) for a first ontology-based approach. Analytics of social knowledge environments need to be developed and hence feasible approaches for content and context extraction of knowledge objects from (social software) systems need to be investigated as means to transfer and re-embed content and context into systems of partner organizations. Analysis of available logs of social software platforms seems promising in this regard (van der Aalst 2012).

Finally, we propose that research should investigate the organizational uptake and deployment of social software, to foster a globally networked organization (online Appendix). Here, especially more empirical research on both the intended and the unintended effects of using social software in organizations is needed. Targeting questions of trust and organizational changes needs input from psychology and social sciences for investigating this interdisciplinary research direction.

\subsection{Social Software in Professional Work Settings}

A key issue relates to the usage, adoption, and impact of social software applications in work settings. The concept of professional work settings draws attention to the connections of social software to (1) individual work settings, i.e. personal workspaces of employees engaged in knowledge work (Kelloway and Barling 2000; Pyöriä 2005), to (2) collaborative work settings, i.e. the workspaces of communities of practice and other social constellations such as work groups, project teams or informal professional networks that support both formal organizational processes and informal organizational practices (Orlikowski 2000) and to (3) organizational work settings, i.e. enterprise systems that primarily support formal organizational processes and practices (Crossan et al. 1999; Nonaka et al. 2006). Analyses of social perspectives often rely on Facebook and Twitter data, hence, on public social software, rather than social software used in professional work settings as it is often much more difficult to obtain data from corporate intranets,. Thus, engaging in work practice studies (Blackler et al. 1993; Orlikowski 2000) reflecting professional activities in workplaces, rather than public social environments, is a key challenge.

Future research pertaining to the organizational dimension should investigate effects of new IT features for improved knowledge acquisition, development and sharing processes, hence, performance of employees in professional 
work settings (Davenport et al. 2002). Social software also raises concerns about how it affects an individual's, a group's or an organization's focus of attention versus distraction from their professional tasks and therefore its effects on task performance (Bailey and Konstant 2006; Kohlegger et al. 2013).

From a technical perspective, we suggest to improve semantic interoperability among social, collaboration and office software, as well as productivity tools for knowledge work and other business applications. We propose the Linked Open Data initiative as a model, which might be transferred to corporate information systems. Passant et al. (2009) detail its advantages for intranet tagging systems. Further research should apply it to other areas such as product mentioning in different documents or systems with varied keywords. Such research also should include interdisciplinary approaches whether computer science to inform interoperability issues or social sciences to clarify the social changes resulting from the use of new technologies.

\subsection{Crowd Knowledge}

Crowd knowledge refers to processes, activities, and resources that are created and deployed by a large, often organizationindependent user base (Yang et al. 2008). This focus area therefore pertains to barriers related to handling knowledge, due to social changes. From the social perspective, the nature of teams in social media-enabled settings has changed considerably since small group research in the 1980s and 1990s.

As a consequence, efforts in future research should lead to an improved understanding of which theories apply to individual, team, or organizational levels in relation to social media support. Some attempts at employing theory-based research in the domain of open innovation and crowdsourcing include, for example, motivation theory (Leimeister et al. 2009) and system theory (Geiger et al. 2011). We also require research that improves our identification of trustworthy mechanisms to enable employees to decide which information should be published within their team, organization, or beyond, instead of emphasizing personalized IT services to foster information exchange and performance (Dondio and Longo 2011). An additional recommendation includes continuing research in the technical dimension on the development of IT integration strategies that acknowledge the challenges of knowledgediverse collaboration settings.

Moreover, from an organizational perspective, the increasing penetration of social media poses a challenge to whether current KM practices allow for appropriate knowledge creation, transfer, and exploitation. If the potential benefits that social media can offer for transferring knowledge within the organization were clear (Lee and Chen 2012; Zheng et al. 2010), research could improve KM in terms of greater trust and thus a willingness to share knowledge throughout the collective, with lower information overload, greater quality and accuracy of knowledge obtained from the crowd, and support for team leaders in assessing the team's knowledge, such that it would facilitate collaboration. According to this, a related legal question involves how to trace authorship and preserve copyrights in such settings (Wolfson and Lease 2011). The BISE/IS discipline can contribute to innovative, cross-disciplinary, research-based solutions. Finally, the IS discipline should emphasize rigorous, design-science research that seeks to develop intelligent task routing and team formation mechanisms (Cosley et al. 2007) as well as social recommendation systems (Guy et al. 2010).

\subsection{Cultural Differences and Cross-border KM}

In distributed settings (across geographical or organizational boundaries), KM raises new challenges related to cultural and contextual differences (Leidner et al. 2006; Noll et al. 2010). This item relates to cultural and contextual barriers. From a social perspective, cultural aspects and $\mathrm{KM}$ across borders are key to understanding social knowledge environments in global settings. In general, we note three main types of cultural research, focused on national, organizational, and team classifications. The need to create, share, and use knowledge across organizational and cultural borders assigns massive potential to this topic in BISE/IS settings. Even as researchers become more involved in international networks, few results stem from comparative or multi-context studies.

On an organizational level, we see a clear need for comparative studies in cross-border and cross-organizational settings that refer to the adoption and diffusion of social KM. For example, research rarely considers the different adoption and acceptance processes that occur between Asia and Europe. As our SLR showed, interdisciplinary research, combined with various methods, is required to understand this phenomenon clearly. From both perspectives - organizational and individual - we see a need to further analyze, improve and validate culture models for KM: a systematic analysis of cultural influence factors needs to be done in interdisciplinary research groups. Furthermore, from an organizational perspective, we need to understand how organizations should organize their cross-border KM, localization, and general adaptation. Technically, social software solutions should be interoperable across systems, languages, and cultures. These challenges call for designoriented research that provides recommendations for collaboration and performance improvement. Although this issue was raised 14 years ago (Katzy et al. 2012), results remain scarce.

\subsection{Methods for Studying Social Knowledge Environments}

Validating design-based innovations in social knowledge environments represents a promising yet challenging research activity. In particular, it is necessary to create validation scenarios across organizational and geographical borders on a more general level than the current isolated, anecdotal evidence available. We must progress from laboratory experiments with student samples to samples of professionals, participating in (near-)field experiments in organizations, and then to longitudinal studies. If researchers can access real-world data sets in actual environments, opportunities abound for increasing the rigor of empirical studies, beyond a dominant method of opinion polls. The result should be a better understanding of the effects of social knowledge environments in organizations, useful for further improvements. Qualitative and quantitative analysis techniques also must be applied to clarify the impact of process and technology changes.

Again, different disciplines should contribute to developing the comprehensive design, adoption, and diffusion of social knowledge environments. The BISE/IS community could promote and facilitate interdisciplinary discourses to es- 
Table 1 Recommended Methods for Topic Areas

\begin{tabular}{|c|c|c|c|c|}
\hline \multirow[t]{2}{*}{ Method } & \multicolumn{4}{|l|}{ Topic area } \\
\hline & $\begin{array}{l}\text { Semi-permeable } \\
\text { organization }\end{array}$ & $\begin{array}{l}\text { Social software in professional } \\
\text { work settings }\end{array}$ & Crowd knowledge & $\begin{array}{l}\text { Cultural differences and } \\
\text { cross-border KM }\end{array}$ \\
\hline $\begin{array}{l}\text { Qualitative } \\
\text { empirical }\end{array}$ & $\begin{array}{l}\text { Knowledge risks arising } \\
\text { from social knowledge } \\
\text { environments }\end{array}$ & $\begin{array}{l}\text { Social software-supported } \\
\text { collaborative practices } \\
\text { performed in professional work } \\
\text { settings }\end{array}$ & $\begin{array}{l}\text { Trust mechanisms and } \\
\text { intention to share }\end{array}$ & $\begin{array}{l}\text { Cultural influence factors; } \\
\text { barriers for specific country } \\
\text { contexts }\end{array}$ \\
\hline $\begin{array}{l}\text { Quantitative } \\
\text { empirical }\end{array}$ & $\begin{array}{l}\text { Effects on knowledge } \\
\text { sharing and the absorptive } \\
\text { capacity in professional } \\
\text { organizational networks }\end{array}$ & $\begin{array}{l}\text { Effects of social software on } \\
\text { (informal and formal) } \\
\text { processes and performance of } \\
\text { employees on the individual, } \\
\text { group and organizational level }\end{array}$ & $\begin{array}{l}\text { Effects of crowd processes } \\
\text { on knowledge creation } \\
\text { and sharing in intra- and } \\
\text { inter-organizational } \\
\text { settings }\end{array}$ & $\begin{array}{l}\text { Comparative studies focusing } \\
\text { on adoption and diffusion of } \\
\text { KM solutions; theories } \\
\text { towards cultural influences } \\
\text { on global social KM }\end{array}$ \\
\hline $\begin{array}{l}\text { Design } \\
\text { science }\end{array}$ & $\begin{array}{l}\text { Adoption of concepts, } \\
\text { models and tools from } \\
\text { information security and } \\
\text { introduction of new } \\
\text { standards }\end{array}$ & $\begin{array}{l}\text { Concepts, models and tools } \\
\text { improving semantic } \\
\text { interoperability between } \\
\text { organizational social software } \\
\text { applications }\end{array}$ & $\begin{array}{l}\text { Concepts, models and } \\
\text { tools improving intelligent } \\
\text { task routing and team } \\
\text { formation }\end{array}$ & $\begin{array}{l}\text { Recommender systems; new } \\
\text { tools (e.g., social } \\
\text { collaboration environments) } \\
\text { for global settings }\end{array}$ \\
\hline
\end{tabular}

tablish the research domain. Intercultural communication research might address social knowledge environments in global contexts (Shuter 2012). The role of social software in societies (e.g., adoption, diffusion issues) might be discussed from a sociological point of view (Han 2010). Educational sciences offer insights into competences and their development (Tess 2013), interlinking activities in social knowledge environments with individual, team, and organizational performance, particularly as they relate to technology-enhanced learning and a strong design orientation (Chan et al. 2006). Customer integration by social software also has been intensely studied in marketing and innovation management fields (Fliess et al. 2011; Kohler et al. 2011). Because innovation in KM is largely driven by technology, computer science topics - particularly interactive design, research in mobile devices, context- and location-aware computing, grid and cloud computing, as well as security and privacy - seem highly relevant. This connection should include methods explored by BISE/IS researchers, such as controlled experiments or ethnography, that are routinely applied in social sciences and psychology. We regard these examples as a starting point for potential interdisciplinary research and discourse. Table 1 summarizes the recommended methods for the discussed topic areas.

\section{Conclusion}

The consumerization of IT and global social media, involving millions of own- ers of devices and users who spend vast amounts of their (paid and unpaid) time participating in social media, create opportunities for revisiting $\mathrm{KM}$ in organizations. In particular, we perceive a chance to deliver on the promise that IS and IT can contribute to improving the productivity and quality of knowledge work, as well as performance of teams and organizations. Yet the existing academic and professional knowledge base is insufficient for designing and deploying social knowledge environments, within and across the boundaries of organizations, compared with the knowledge base available about global, public social media.

Although the past decade has experienced strong trends toward the integration of human- and technology-centered research streams, as well as new technology approaches (e.g., semantic web, ontology concepts for KM; Lee and Chen 2012), we have sought to summarize the current state of the emerging research area related to social knowledge environments from different perspectives. We identified four research strands and a methodological arrangement that appear promising for ongoing research conducted by the BISE/IS community. How do we proceed from here? We encourage researchers to (1) address the four research areas with combinations of theory-led design science research, employing controlled experiments and field studies that go beyond opinion polls and rely on data collected in actual social knowledge environments; (2) pursue interdisciplinary research and engage in projects that combine researchers' complementary competencies, to master the methodological issues that arise from the study of complex social phenomena in real-world organizations; (3) create innovation through design-oriented solutions, including designs of business models, processes, software tools, and services; (4) systematically analyze global challenges and differences using comparative or multi-context studies to investigate different adoption and acceptance patterns across countries and continents; and (5) support diffusion and adoption through standardization, to sustainably transfer research results to a broad range of professionals and organizations.

\section{References}

Ågerfalk P, Fitzgerald B, Holmstroem H (2005) A framework for considering opportunities and threats in distributed software development. In: Proc of international workshop on distributed software development. Austrian Computer Society, Paris, pp 47-61

Alavi M, Leidner DE (2001) Review: knowledge management and knowledge management systems: conceptual foundations and research issues. MIS Quarterly 25(1):107-136

Alstete J (2003) Trends in corporate knowledge asset protection. Journal of Knowledge Management Practice 4

Avram G (2006) At the crossroads of knowledge management and social software. Electronic Journal of Knowledge Management 4(1):1-10

Bailey BP, Konstant J (2006) On the need for attention-aware systems: measuring effects of interruption on task performance, error rate, and affective state. Computers in Human Behavior 22(4):685-708

Barnes S, Bimrose J, Brown A, Feldkamp D, Kaschig A, Kunzmann C, Maier R, Nelkner 
T, Sandow A, Thalmann S (2009) Knowledge maturing at workplaces of knowledge workers: results of an ethnographically informed study. In: Tochtermann K, Maurer $\mathrm{H}$ (eds) Proc of 9th international conference on knowledge management and knowledge technologies, Graz, pp 1427

Bayer F, Maier R (2006) Knowledge risks in inter-organizational knowledge transfer. In: Proc of I-KNOW'06, Graz

Blackler F, Reed M, Whitaker A (1993) Epilogue - an agenda for research. Journal of Management Studies 30(6):1017-1020

Brambilla $M$, Fraternali $P$, Vaca Ruiz CK (2012) Combining social web and BPM for improving enterprise performances: the BPM4People approach to social BPM. In: Proc of 21 st international conference companion on world wide web, pp 223-226

Brereton P, Kitchenham BA, Budgen D, Turner M, Khalil M (2007) Lessons from applying the systematic literature review process within the software engineering domain. Journal of Systems and Software 80(4):571-583

Campisi P, Maiorana E, Neri A (2009) Privacy protection in social media networks a dream that can come true? In: Proc of 16th international conference on digital signal (DSP'09), New Jersey, pp 254-258

Cha M, Kwak H, Rodriguez P, Ahn YY, Moon S (2007) I tube, you tube, everybody tubes: analyzing the world's largest user generated content video system. In: Proc of ACM SIGCOMM Internet measurement conference (IMC), San Diego

Chan T, Roschelle J, Hsi S, Kinshuk Sharples $M$, Brown T, Patton C, Cherniavsky J, Pea $R$, Norris $C$, Soloway $E$, Balacheff N, Scardamalia M, Dillenbourg P, Looi C, Milrad M, Hoppe U (2006) One-to-one technology-enhanced learning: an opportunity for global research collaboration. Research and Practice in Technology Enhanced Learning 1(1):3-29

Choi SY, Lee H, Yoo Y (2010) The impact of information technology and transactive memory systems on knowledge sharing application, and team performance: a field study. MIS Quarterly 34(4):855-870

Cook N (2008) Enterprise 2.0: how social software will change the future of work. Ashgate Publishing Company, Aldershot

Cosley D, Frankowski D, Terveen L, Riedl J (2007) SuggestBot: using intelligent task routing to help people find work in Wikipedia. In: Proc of 12th international conference on intelligent user interfaces, New York, pp 32-41

Crossan MM, Lane HW, White RE (1999) An organizational learning framework: from intuition to institution. Academy of Management Review 24(3):522-537

Davenport TH, Thomas RJ, Cantrell $\mathrm{S}$ (2002) The mysterious art and science of knowledge-worker performance. MIT Sloan Management Review 44(1):23-30

DeSanctis G, Poole MS (1994) Capturing the complexity in advanced technology use: adaptive structuration theory. Organization Science 5(2):121-147

DiMicco J, Millen DR, Geyer W, Dugan C, Brownholtz B, Muller M (2008) Motivations for social networking at work. In: Inkpen K, Tang J (eds) Proc of ACM 2008 conference on computer supported cooperative work (CSCW'08), San Diego, pp 711-720

Dondio P, Longo L (2011) Trust-based techniques for collective intelligence in social search systems. In: Bessis N, Xhafa F (eds)
Next generation data technologies for collective computational intelligence $\mathrm{SE}$, vol 5 . Springer, Berlin, pp 113-135

Drakos N, Mann J, Sarner A (2012). Magic quadrant for social software in the workplace. Gartner

Drucker PF (1994) The age of social transformation. Atlantic Monthly 274:53-80

Fliess S, Jacob F, Fandel G (2011) Von der Kundenintegration 1.0 zur Kundenintegration 2.0: Implikationen für Praxis und Forschung. Zeitschrift für Betriebswirtschaft 81(5):5-20

Geiger D, Rosemann M, Fielt E (2011) Crowdsourcing information systems - a systems theory perspective. In: Proc of 22nd Australasian conference on information systems. Sydney

Gundecha P, Liu H (2012) Mining social media: a brief introduction. In: Mirchandani P (ed) INFORMS TutORials in operations research, vol 9. INFORMS, Hanover, pp 1-17

Gupta A, Seshasai S (2007) 24-Hour knowledge factory: using Internet technology to leverage spatial and temporal separations. ACM Transactions on Internet Technology 7(3):14

Guy I, Zwerdling N, Ronen I, Carmel D, Uziel E (2010) Social media recommendation based on people and tags. In: Proc of 33rd international ACM SIGIR conference on research and development in information retrieval, pp 194-201

Haller K (2009) Towards the industrialization of data migration: concepts and patterns for standard software implementation projects. Advanced Information Systems Engineering 5565:63-78

Han S (2010) Theorizing new media: reflexivity, knowledge, and the web 2.0. Sociological Inquiry 80:200-213

Happel HJ, Maalej W, Stojanovi L (2008) Team: towards a software engineering semantic web. In: Proc of 2008 international workshop on cooperative and human aspects of software engineering, pp 57-60

Heisig P (2009) Harmonisation of knowledge management - comparing $160 \mathrm{KM}$ frameworks around the globe. Journal of Knowledge Management 13(4):4-31

Hemsley J, Mason RM (2013) Knowledge and knowledge management in the social media age. Journal of Organizational Computing and Electronic Commerce 23(1-2):138167

Hippner H, Wilde T (2005) Social software. WIRTSCHAFTSINFORMATIK 47(6):441-444

Holsapple CW, Joshi KD (2002) Knowledge manipulation activities: results of a Delphi study. Information \& Management 39(6):477-490

Jackson P (2010) Capturing, structuring and maintaining knowledge: a social software approach. Industrial Management \& Data Systems 110(6):908-929

Jarvenpaa SL, Majchrzak A (2010) Research commentary - vigilant interaction in knowledge collaboration: challenges of online user participation under ambivalence. Information Systems Research 21(4):773-784

Kamsu Foguem B, Coudert T, Béler C, Geneste $L$ (2008) Knowledge formalization in experience feedback processes: an ontologybased approach. Computers in Industry 59(7):694-710

Kanawattanachai $P$, Yoo $Y$ (2007) The impact of knowledge coordination on virtual team performance over time. MIS Quarterly 31(4):783-808

Kaplan AM, Haenlein M (2010) Users of the world, unite! The challenges and opportu-

\section{Abstract}

Jan M. Pawlowski, Markus Bick, René Peinl, Stefan Thalmann, Ronald Maier, Lars Hetmank, Paul Kruse, Malte Martensen, Henri Pirkkalainen

\section{Social Knowledge Environments}

Knowledge management represents a key issue for both information systems' academics and practitioners, including those who have become disillusioned by actual results that fail to deliver on exaggerated promises and idealistic visions. Social software, a tremendous global success story, has prompted similarly high expectations regarding the ways in which organizations can improve their knowledge handling. But can these expectations be met, whether in academic research or the real world? This article seeks to identify current research trends and gaps, with a focus on social knowledge environments. The proposed research agenda features four focal challenges: semi-permeable organizations, social software in professional work settings, crowd knowledge, and crossborder knowledge management. Three solutions emerge as likely methods to address these challenges: designoriented solutions, analytical solutions, and interdisciplinary dialogue.

Keywords: Distributed team, Global team, Information system, Knowledge management, Organization, Social networking, Social software, Tools 
nities of social media. Business Horizons 53(1):59-68

Kärkkäinen H, Jussila J, Väisänen J (2010) Social media use and potential in businessto-business companies' innovation. In: Proc of 14th international academic mindtrek conference on envisioning future media environments (MindTrek '10), Tampere, pp 228-236

Katzy BR, Bondar K, Mason RM (2012) Knowledge-based theory of the firm challenges by social media. In: 45th Hawaii international conference on system science (HICSS), pp 3879-3887

Kelloway EK, Barling J (2000) Knowledge work as organizational behavior. Internationa Journal of Management Reviews 2(3):287304

Kohlegger M, Maier R, Remus U (2013) Freedom of choice: perspectives on personal workspaces. In: Proc of 21st European conference on information systems (ECIS 2013). AIS electronic library, pp 1-12

Kohler T, Füller J, Matzler K, Stieger D (2011) Co-creation in virtual worlds: the design of the user experience. MIS Quarterly 35(3):773-778

Krcmar H (2005) Informationsmanagement. Springer, Berlin

Lee MR, Chen TT (2012) Revealing research themes and trends in knowledge management: from 1995 to 2010 . KnowledgeBased Systems 28:47-58

Lei Zeng M, Mai Chan L (2004) Trends and issues in establishing interoperability among knowledge organization systems. Journal of the American Society for Information Science and Technology 55(5):377-395

Leidner D, Alavi M, Kayworth TR (2006) The role of culture in knowledge management: a case study of two global firms. International Journal of e-Collaboration 2(1):1740

Leimeister JM, Huber M, Bretschneider U, Krcmar H (2009) Leveraging crowdsourcing: activation-supporting components for ITbased ideas competition. Journal of Management Information Systems 26(1):197224

Levy M (2009) WEB 2.0 implications on knowledge management. Journal of Knowledge Management 13(1):120-134

Maier R (2007) Knowledge management systems: information and communication technologies for knowledge management. Springer, Berlin

Maier R, Hädrich T, Peinl R (2009) Enterprise knowledge infrastructures, 2nd edn. Springer, Berlin

Majchrzak A, Malhotra A, John R (2005) Perceived individual collaboration know-how development through information technology? Enabled contextualization: evidence from distributed teams. Information Systems Research 16(1):9-27

Manhart M, Thalmann S (2013) An integrated risk management framework: measuring the success of organizational knowledge protection. In: Proc of 19th Americas conference on information systems. AIS Electronic Library, Chicago

Markus ML, Silver MS (2008) A foundation for the study of IT effects: a new look at DeSanctis and Poole's concepts of structural features and spirit. Journal of the Association for Information Systems 9(10):609-632

Müller J, Stocker A (2011) Enterprise microblogging for advanced knowledge sharing: the References@BT case study. The Journal of Universal Computer Science 17(4):532-547

Noll J, Beecham S, Richardson I (2010) Global software development and collaboration: barriers and solutions. ACM Inroads 1(3):66-78

Nonaka I, von Krogh G, Voelpel S (2006) Organizational knowledge creation theory: evolutionary paths and future advances. Organization Studies 27(8):1179-1208

Nunes VT, Santoro FM, Borges MR (2009) A context-based model for knowledge management embodied in work processes. Information Sciences 179(15):2538-2554

Olander $\mathrm{H}$, Hurmelinna-Laukkanen P, Heilmann P (2011) Do SMEs benefit from HRM related knowledge protection in innovation management? International Journal of Innovation Management 15(3):593-616

Onyechi GC, Abeysinghe G (2009) Adoption of web based collaboration tools in the enterprise: challenges and opportunities. In: Proc of international conference on the current trends in information technology (CTIT'09), pp 1-6

O'Reilly T (2005) What Is web 2.0 - design patterns and business models for the next generation of software. http://oreilly.com/ web2/archive/what-is-web-20.html. Accessed 2013-03-04

Orlikowski WJ (2000) Using technology and constituting structures: a practice lens for studying technology in organizations. Organization Science 11(4):404-428

Oshri I, van Fenema P, Kotlarsky J (2008) Knowledge transfer in globally distributed teams: the role of transactive memory. Information Systems Journal 18(6):593-616

Otter T (2007) Data protection law: the Cinderella of the software industry? Computer Law \& Security Review 23(1):67-72

Pallot M, Martínez-Carreras MA, Prinz W (2010) Collaborative distance. Internationa Journal of e-Collaboration 6(2):1-32

Panetto H, Molina A (2008) Enterprise integration and interoperability in manufacturing systems: trends and issues. Computers in Industry 59(7):641-646

Passant A, Laublet P, Breslin JG, Decker S (2009) A URI is worth a thousand tags: from tagging to linked data with moat. International Journal on Semantic Web and Information Systems 5(3):71-94

Peinl $R$, Hetmank $L$, Bick $M$, Thalmann $S$, Kruse $\mathrm{P}$, Pawlowski JM, Maier R, Seeber I (2013) Gathering knowledge from social knowledge management environments: validation of an anticipatory standard. In: Proc of 11th international conference on Wirtschaftsinformatik, Leipzig

Pirkkalainen H, Pawlowski JM (2013) Global social knowledge management - understanding barriers for global workers utiliz ing social software. Computers in Human Behavior 30:637-647

Pyöriä P (2005) The concept of knowledge work revisited. Journal of Knowledge Management 9(3):116-127

Richter D, Riemer PDK, vom Brocke J (2011) Internet social networking: research state of the art and implications for enterprise 2.0. Bus Inf Syst Eng 3(2):89-101

Schweitzer L, Duxbury L (2010) Conceptualizing and measuring the virtuality of teams. Information Systems Journal 20(3):267295

Serenko A, Bontis N, Booker L, Sadeddin K, Hardie T (2010) A scientometric analysis of knowledge management and intellectual capital academic literature (19942008). Journal of Knowledge Management 14(1):3-23

Shuter R (2012) Intercultural new media studies: the next frontier in intercultural communication. Journal of Intercultural Communication Research 41(3):219-237

Staples DS, Webster J (2008) Exploring the effects of trust, task interdependence and virtualness on knowledge sharing in teams. Information Systems Journal 18(6):617640

Tess PA (2013) The role of social media in higher education classes (real and virtual) - a literature review. Computers in Human Behavior 29(5):A60-A68

Thomas DM, Bostrom RP (2010) Vital signs for virtual teams: an empirically developed trigger model for technology adaptation interventions. MIS Quarterly 34(1):115-142

van der Aalst W (2012). Process mining manifesto: toward real business intelligence

Väyrynen K, Hekkala R, Liias T (2013) Knowledge protection challenges of social media encountered by organizations. Journal of Organizational Computing and Electronic Commerce 23(1-2):34-55

vom Brocke J, Becker J, Braccini MA, Butleris $R$, Hofreiter B, Kapočius $K$, De Marco $M$, Schmidt G, Seidel S, Simons A, Skopal T, Stein A, Stieglitz S, Suomi R, Vossen G, Winter R, Wrycza S (2011) Current and future issues in BPM research: a European perspective from the ERCIS meeting 2010. Communications of the Association for Information Systems 28:25

von Krogh G (2012) How does social software change knowledge management? Toward a strategic research agenda. The Journal of Strategic Information Systems 21(2):154164

Wallace DP, Van Fleet C, Downs LJ (2011) The research core of the knowledge management literature. International Journal of Information Management 31(1):14-20

Webster J, Watson RT (2002) Analyzing the past to prepare for the future: writing a literature review. MIS Quarterly 26(2):xiiixxiii

Wolfson SM, Lease M (2011) Look before you leap: legal pitfalls of crowdsourcing. Proc American society for information science and technology 48(1):1-10

Yang J, Adamic LA, Ackerman MS (2008) Crowdsourcing and knowledge sharing: strategic user behavior on taskcn. In: Proc of 9th ACM conference on electronic commerce, pp 246-255

Yu J, Benatallah B, Casati F, Daniel F (2008) Understanding mashup development. Internet Computing 12(5):44-52

Zheng Y, Li L, Zheng F (2010) Social media support for knowledge management. In: Proc of international conference on management and service science (MASS'10), pp $1-4$ 